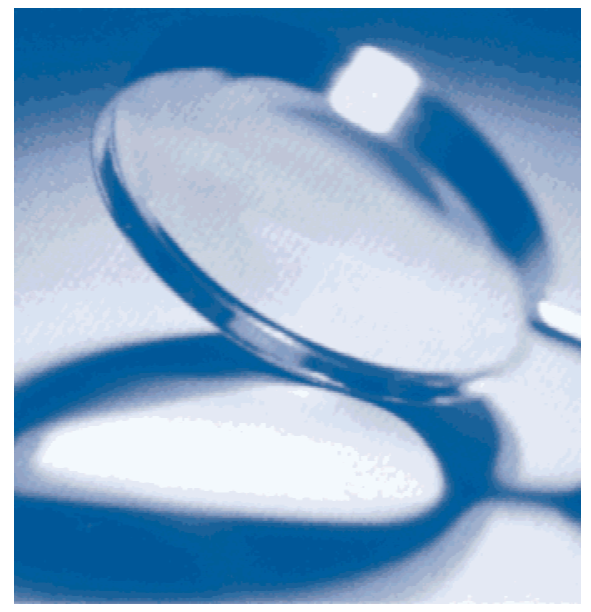

In the Public Eye

\title{
News and Features
}

\section{Compensation awarded for death after illegible prescription}

Fred Charatan, Florida

A Texas jury has attributed the death of a 42 year old patient to an illegible prescription and has ordered the doctor who wrote it to pay $\$ 225,000$ compensation to the patient's family. The total judgment of $\$ 450,000$ included an equal award against the dispensing pharmacist.

The doctor, cardiologist Dr Ramachandra Kolluru, wrote a prescription for $20 \mathrm{mg}$ Isordil (isosorbide dinitrate) for angina, every six hours. But, because of the illegibility of the prescription, argued Kent Buckingham, lawyer for the family of the patient, Ramon Vasquez, the pharmacist dispensed the same dosage of Plendil (felodipine), a calcium channel blocker used in the treatment of hypertension, for which the maximum daily dose is only $10 \mathrm{mg}$. A day after taking what equalled a $16 \%$ overdose of felodipine, $\mathrm{Mr}$ Vasquez had a heart attack and died several

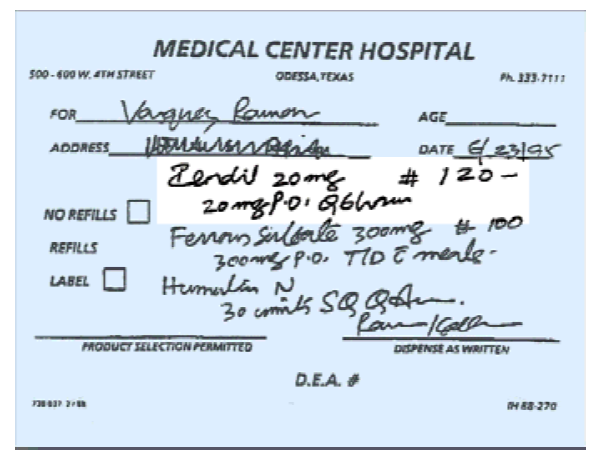

The illegible prescription days later. The overall quality of care given by Dr Kolluru was not at issue, the jury heard; his illegible prescription was the sole reason for the judgment.

The case again raises the issue of the legibility of doctors' handwriting. Mr Buckingham pointed out: "Many doctors are having to stop and think, "That prescription I wrote illegibly this morning may result in an adverse verdict.'”

Three policies issued over the past 7 years by the American Medical Association have urged doctors to "improve the legibility of handwritten orders for medications" and to review all orders for accuracy and legibility after writing them. Doctors with poor handwriting are advised to use direct, computerised order entry systems or at least to print or type medication orders. Dr Kolluru's lawyer, Max Wright, said after the trial: "This jury clearly questioned why in the electronic age ... we're still using this antiquated system based on a three and a half by five inch piece of paper."

A trustee of the American Medical Association, Donald Palmisaro, noted that reducing all sources of medication errors is a top priority of the National Patient Safety Foundation at the association. In addition, the US Adopted Names Council, housed in the association, aims to reduce such errors by helping drug manufacturers to avoid drug names that look or sound alike.

\section{US board of education advises against drugs for behavioral problems}

Fred Charatan, Florida

A US board of education has passed a resolution urging teachers to use discipline and instruction to overcome problem behavior in the classroom, rather than encouraging parents to seek drug treatment for their children.
The resolution passed by Colorado Board of Education carries no legal weight but sounds a warning on the growing use of drugs such as Ritalin (methylphenidate hydrochloride) to deal with disruptive behavior 
in schools. Board members supporting the resolution believed that many violent crimes committed by school students are committed by young people taking psychotropic drugs. In the massacre last spring at Columbine High School in Littleton, Colorado, one of the teenage shooters, Eric Harris, had been taking the antidepressant Luvox (fluvoxamine).

The board's action, believed to be the first in the United States, is sure to intensify the debate over the use of psychotropic drugs in conditions such as attention deficit hyperactivity disorder. An estimated 2.5 million children in the United States are now taking drugs for this type of problem.
Peter Breggin, director of the International Center for the Study of Psychiatry and Psychology, a non-profit research organization in Bethesda, MD, believes that doctors are overprescribing psychotropic drugs. "It's a tremendous mistake to subdue the behavior of children instead of tending to their needs," he said. He is convinced there is a direct link between the drugs and violent acts.

The use of psychotropic drugs in children with attention deficit hyperactivity disorder was examined last May in the Journal of the American Academy of Child and Adolescent Psychiatry. A review of a sample of nearly 1300 children in four US communities showed an overall rate of the disorder of about 5\%, based on formal diagnostic criteria. Results showed that fewer than one in eight children with the disorder received stimulant drugs. Reassuringly, the researchers concluded that children with the disorder were more likely to receive other forms of treatment than to receive stimulants.

Stephen Stahl, a professor of psychiatry at the University of California in San Diego, said: "If a kid is acting out in class and a stimulant like Ritalin calms him down, it would be immoral not to give him the medicine." He cautioned, however, against giving such treatment in isolation, "as an excuse to avoid tough decisions, or talking with teachers and doctors to learn what's going on."

\section{HMO sues charity over domain name}

Douglas Carnall, BMJ, London, UK

A large Californian health maintenance organization is suing a health charity because it wants its Internet domain name. HealthNet is owned by Foundation Health Systems and looks after 2.2 million Californians with a budget of $\$ 8.9$ billion. In contrast, SatelLife, which owns the HealthNet.org domain name, has an annual budget of just over $\$ 1$ million. It helps health workers in 164 countries access health information using email and a cheap low orbit satellite connection.

HealthNet registered its name as a trademark in 1981, but did not register HealthNet.net and HealthNet.com as domain names until 3 years after SatelLife registered HealthNet.org in May 1993.

The charity does not want to give way. "Changing the domain names would involve reprogramming machines in many remote developing world locations, as well as the satellite," said SatelLife director Holly Ladd. "We estimate it would cost more than \$1 million to do, and create considerable confusion amongst our overseas users. There is little likelihood that users would confuse healthnet.org with healthnet.com. After all, they plan to spend $\$ 20$ million on their web presence alone next year."

The charity is also unhappy about the
$\$ 7000$ legal bill the action has already incurred, although its future costs are being met on a pro bono basis by a sympathetic legal firm. Until 1993, domain name registration was under the aegis of a single organization, Network Solutions, who tightly maintained access to the coveted ".com" ".org" ".net" and ".edu" domains.

The process was fully privatized in 1998 . The history of this process is described at www. networksolutions.com/internic/internic.html. The non-profit organization that oversees the domain name registration companies is ICANN. Its policy on dispute resolution is at www. icann.org/udrp/udrp-policy-24oct99.htm.

\section{Passive smoking is more risky for women with a missing gene}

Scott Gottlieb, New York

The combination of environmental tobacco smoke and a missing gene may make some women up to six times more likely to develop lung cancer if they are exposed to second hand smoke, according to the results of a new study. The lead author, Dr William P Bennett of the National Cancer Institute in Bethesda, Maryland, and colleagues set out to determine if common genetic polymorphisms associated with the activation or detoxification of carcinogenic agents found in environmental tobacco smoke were associated with an increased vulnerability to lung cancer.
They tested for the genetic alterations in the archived tissue samples of 106 white Missouri women, mostly rural housewives, who had never smoked but had nevertheless been given a diagnosis of lung cancer. Researchers found that those women lacking a specific gene were more likely to develop lung cancer as a result of second hand smoke and that they showed a rising trend in their risk of developing lung cancer with increasing smoke exposure ( J Natl Cancer Inst 1999;91:2009-2014).

The researchers identified a significant interaction of gene and environment among the women, in which a specific genetic alter- ation seemed to make women more susceptible to the carcinogenic effects of environmental tobacco smoke. The alteration caused a deficiency in a compound called glutathione-S-transferase M1 that, under normal circumstances, is used by the body to detoxify certain carcinogens commonly found in tobacco smoke.

As the exposure to environmental tobacco smoke increased, so did the risk of lung cancer for women with the gene deletion, reaching a more than sixfold increase in risk in women exposed to the highest levels of environmental smoke. 